\title{
Pengembangan Kewirausahaan Sosial Pada Perguruan Tinggi Melalui Social Project Competition
}

\author{
Lak lak Nazhat El Hasanah \\ Fakultas Ekonomi Universitas Islam Indonesia \\ lak_lak@uii.ac.id
}

\begin{abstract}
ABSTRAK
Kewirausahaan sosial merupakan suatu konsep yang dapat menyelesaikan masalah sosial dengan pendekatan bisnis. Kewirausahaan sosial yang ideal dan terarah serta berkelanjutan bisa dilakukan melalui kegiatan pendidikan yang berorientasi pada pengembangan wirausaha sosial dari kalangan mahasiswa. Sebagai generasi muda, mahasiswa merupakan agent of change yang dapat memberikan perubahan sosial ekonomi dengan memberikan peluang baru bagi masyarakat. Tujuan tulisan ini adalah untuk mengetahui pengembangan kewirausahaan sosial pada perguruan tinggi dengan menggambarkan suatu program pengembangan kewirausahaan sosial tersebut. Metode penelitian adalah deskriptif kualitatif sedangkan penentuan sampel dilakukan dengan metode purposive random sampling. Pengumpulan data menggunakan kombinasi pendekatan yang meliputi survei, observasi, studi lapangan, dan interview. Hasil penelitian menunjukkan bahwa pelaksanaan pengembangan kewirausahaan sosial dilakukan dalam bentuk kompetisi dengan judul program Social Project Competition. Program ini diharapkan dapat menciptakan lulusan yang mempunyai kemandirian usaha sekaligus kepekaan sosial serta memberikan keseimbangan kemampuan akademis, bersikap, dan berkarya dalam rangka menuju pengembangan diri masyarakat, baik sebagai wirausaha sosial yang profesional, mandiri, dan inovatif. Kompetisi ini diperuntukkan bagi mahasiswa yang memiliki minat dalam pengembangan bisnis berbasis sosial. Hasil kompetisi diperoleh tiga pemenang yang memenuhi unsur sociopreneur yaitu Social Value, Civil Society, Innovation, Economic Activity. Adapun pemenang kompetisi adalah pemberdayaan masyarakat dan pengembangan ekonomi pengolahan sampah popok di bantaran Kali Code, Mimpi Kita, dan SUKAWA (Susu Kambing Etawa). Pemenang kompetisi diharapkan dapat menciptakan bisnis sosial yang meningkatkan kesejahteraan masyarakat.
\end{abstract}

KATA KUNCI Social Project | Sociopreneur | Perguruan Tinggi | Inovatif

\section{PENDAHULUAN}

Mahasiswa merupakan agent of change dalam peningkatan kapasitas masyarakat di sekitarnya. Sebagai generasi milenial, mahasiswa harus jeli terhadap adanya transformasi jenis pekerjaan yang lebih tidak terlihat formal. Bagi mahasiswa, persiapan diri sangat diperlukan sehingga ketika lulus mahasiswa tidak kebingungan mencari pekerjaan dan tidak menambah jumlah pengangguran di Indonesia. Untuk itu suatu solusi nyata sangat diperlukan untuk mengatasi hal tersebut, salah satunya adalah meningkatkan semangat kewirausahaan pada setiap individu mahasiswa agar bisa melihat peluang untuk menciptakan inovasi-inovasi yang kreatif dari potensi lokal yang dimiliki oleh masyarakat. Kewirausahaan sosial misalnya, menjadi salah satu bentuk perubahan baik karena konsep-konsep yang diangkat adalah membangun bisnis untuk masalah sosial, ekonomi, dan lingkungan. Sebagai agent of change, mahasiswa berkewajiban mengubah diri dan masyarakat untuk lebih mandiri dalam upaya meningkatkan kesejahteraannya melalui program-program yang ada dalam perguruan tinggi. Peningkatan semangat berwirausaha 
pada setiap individu yang ada di masyarakat merupakan salah satu hal yang dapat dilakukan oleh mahasiswa sebagai agen perubahan dalam meningkatkan kesejahteraan masyarakat. Kewirausahaan sosial (Sociopreneurship) merupakan kewirausahaan berbasis sosial yang ditujukan untuk kepentingan masyarakat bukan sekadar keuntungan pribadi, kewirauhaan sosial ini bisa dilakukan secara individu maupun organisasi (Tan, Williams and Tan 2005). Dees (2001) dalam bukunya yang berjudul "The Meaning of Social Entrepreneurship" mendefinisikan sociopreneurship sebagai kombinasi dan semangat besar dalam misi sosial yang diiringi dengan kedisiplinan, inovasi, dan keteguhan seperti yang lazim berlaku di dunia bisnis.

Perguruan tinggi merupakan salah satu organisasi yang bergerak di bidang pendidikan. Keterlibatan perguruan tinggi dalam pendidikan kewirausahaan sosial pada mahasiswa akan menghasilkan wirausahawan, kerjasama dengan perusahaan industri, masyarakat yang terlibat langsung dengan program pengembangan kewirausahaan sosial, hingga model maupun teori-teori baru yang lahir dari hasil penelitian yang terukur, terarah, dan berkelanjutan. Sebagai bentuk pengembangan kewirausahaan di kalangan mahasiswa, perguruan tinggi perlu menanamkan jiwa entrepreneur kepada mahasiswa yang mempunyai kepekaan sosial tersendiri, sehingga dapat melakukan edukasi pada masyarakat dengan efektif, terarah, dan terukur terkait program meningkatkan kesejahteraan melalui sociopreneur. Masturin (2015) menyatakan bahwa pemberdayaan human capital memiliki kemampuan untuk mengantarkan manusia pada pemikiran-pemikiran yang rasional, sadar, dan kritis untuk keluar dari problematikanya dan memberikan dampak timbal balik untuk membantu persoalan sosial lainnya sehingga peran lembaga pendidikan pada kenyataannya mampu menerapkan pemberdayaan malalui sociopreneurship. Penerapan strategi-strategi untuk menghasilkan generasi yang memiliki jiwa wirausaha berbasis sosial masyarakat menjadi sebuah prestasi tersendiri bagi perguruan tinggi tersebut. Selain itu, sociopreneurship menjadi tren pemuda masa kini sebagai alternatif dalam bertahan hidup di tengah kesempitan dalam mencari pekerjaan (Suyatna and Nurhasanah 2017).
Social Project Competition merupakan salah satu strategi yang diterapkan oleh salah satu perguruan tinggi swasta di Yogyakarta. Strategi ini mengharuskan mahasiswanya untuk lebih dekat dengan masyarakat karena sebelum melakukan proyeknya mahasiswa harus mengenal masyarakat yang akan jadi sasaran. Luaran program Social Project Competition adalah terciptanya mahasiswa yang peka terhadap permasalahan sosial yang berdampak terjadinya perubahan di masyarakat dalam bidang ekonomi. Selain itu juga bisa menumbuhkan kepekaan mahasiswa terhadap peluang usaha bagi dirinya sendiri dan masyarakat. Selain itu, Social Project Competition merupakan merupakan program bantuan ilmu pengetahuan, teknologi, dan seni dalam upaya peningkatan kinerja organisasi kemasyarakatan. Berdasarkan uraian di atas permasalahan yang cukup menggelitik penulis untuk mengupasnya lebih jauh adalah bagaimana pelaksanaan Social Project Competition di perguruan tinggi tersebut agar mampu menghasilkan lulusan wirausaha sosial dan sejauh mana keberhasilan kegiatan tersebut dapat meningkatkan ekonomi masyarakat. Aspek penting yang menjadi poin dalam tulisan ini adalah bagaimana perguruan tinggi menjadi pencetak sociopreneurship baru di Indonesia.

Kompetisi ini diperuntukkan bagi mahasiswa yang masih aktif sebagai bentuk penyiapan entrepreneur muda yang memiliki kepekaan terhadap perubahan masyarakat dalam bidang pendidikan, lingkungan, dan ekonomi. Sebagai peserta Social Project Competition, mahasiswa harus terus mencari peluang dan menciptakan berbagai aktivitas inovatif untuk meningkatkan taraf ekonomi dan sosial masyarakat marjinal dan memahami persoalan sosial dengan kemampuan kewirausahaan yang dimiliki untuk meningkatkan kesejahteraan masyarakat dalam bidang pendidikan, lingkungan, dan ekonomi. Dalam menciptakan inovasi mahasiswa harus memahami model bisnis social entrepreneurship Menurut Kusumasari dkk (2015) terdapat tiga aspek jenis desain bisnis sociopreneurship, yaitu; preposisi nilai, penciptaan nilai, dan tangkapan nilai. Preposisi nilai berkaitan dengan pembentukkan organisasi, tujuan yang ingin dicapai bisnis, isu sosial yang ingin dijawab, siapa yang menjadi pelanggannya, dan apa yang 
ditawarkan kepada pelanggan atau pengguna jasa atau produk bisnis, penciptaan nilai mencakup aktivitas bisnis untuk mencapai nilai bisnis, cara kerja, keberlanjutan suatu perusahaan dengan siapa perusahaan melakukan kerja sama, dan pembiayaan aktivitas suatu bisnis, sedangkan tangkapan nilai cara bisnis mendapatkan keuntungan, definisi sukses bagi suatu bisnis, dan pengukuran kinerja sociopreneur atau dalam pencapaian kinerja.

\section{KERANGKA TEORI}

\section{A. Sociopreneurship}

Sociopreneurship atau kewirausahaan sosial sekarang menjadi sebuah tren di perguruan tinggi sebagai implementasi tri dharma yang berbasis pengabdian masyarakat. Berbagai metode pendidikan dan pelatihan merupakan metode pendidikan yang ditawarkan dalam peningkatan skill wirausaha untuk bisa diimplementasikan di masyarakat. Asal kata Sociopreneurship adalah social dan entrepeneurship yang berarti sebagai orang/organisasi yang memahami permasalahan sosial dan menggunakan kemampuan entrepreneurship untuk melakukan perubahan sosial. Secara sederhana Socipreneurship atau kewirausahaan sosial merupakan tindakan seseorang yang mengerti permasalahan sosial dan menggunakan kemampuan entrepreneurship untuk melakukan perubahan sosial, baik bidang kesejahteraan, pendidikan maupun kesehatan (Santoso 2007). Menurut Wiguna (2013), Social Entrepreneur merupakan gagasan yang muncul pertama kali dari sistem ekonomi di wilayah Eropa yang berorientasi pada proses dan perilaku tujuannya adalah meningkatkan aspek sosial serta menerapkan strategi terintegrasi antara aspek sosial dan ekonomi sehingga performanya dapat diketahui dari kontribusi yang diberikan dalam upaya meningkatkan aspek sosial.

Konsep kewirausahaan sosial merupakan perluasan dari konsep dasar kewirausahaan yang secara historis telah diakui sebagai pengungkit ekonomi, terutama dalam menyelesaikan masalah sosial (Noruzi, et.al 2010; Patra and Nath 2014). Perilaku individu dalam berwirausaha ini merupakan suatu upaya dalam memanfaatkan peluang dan menciptakan suatu nilai. Untuk sociopreneurship, nilai yang dituju adalah nilai sosial sebab kewirausahaan sosial sangat menekankan bagaimana menciptakan ide atau gagasan yang bersifat inovatif dalam rangka menyelesaikan permasalahan sosial. Empat elemen utama dalam kewirausahaan sosial antara lain, social value, civil society, innovation, dan economic activity. (Hulgard 2010). Social Value adalah adanya manfaat sosial yang nyata bagi masyarakat dan lingkungan sekitar, Civil Society merupakan bentuk inisiatif dan partisipasi masyarakat sipil dengan mengoptimalkan modal sosial yang ada di masyarakat, Innovation merupakan inovasi yang dilakukan dalam pemecahan masalah dengan melihat kearifan lokal masyarakat, sedangkan Economic Activity merupakan keseimbangan antara aktivitas sosial dan aktivitas bisnis untuk menjamin kemandirian dan keberlanjutan misi sosial organisasi.

Konsep sociopreneur sudah lama dan sudah dikembangkan di universitas-universitas salah satunya universitas yang ada di Inggris seperti Skoll Center for Social Entrepreneurship di Oxford University. Di Amerika Serikat juga didirikan pusat-pusat kajian social entrepreneurship, contohnya Center for the Advancement of Social entrepreneurship di Duke University. Contoh praktik social entrepreneurship, terdapat pada yayasan yang sudah mengglobal, yang secara khusus mencari para social entrepreneur di berbagai belahan dunia untuk membina dan memberikan dananya bagi para penggerak perubahan sosial yakni Ashoka Foundation (Nicholls 2006).

Di Indonesia, istilah sociopreneur mulai menjadi tren anak muda. Terbukti beberapa social entrepreneur muda telah berhasil berkontribusi dalam penyelesaian masalah sosial ekonomi masyarakat. Penelitian (Suyatna and Nurhasanah 2017) menunjukkan bahwa pemuda dengan berbagai teknologi yang sangat cepat dan canggih telah mulai mencari peluang bisnis sosial sebagai pilihan bertahan hidup di tengah kesempitan mereka dalam mencari pekerjaan. Adanya teknologi yang semakin canggih juga dimanfaatkan oleh pemuda untuk modal bisnis yang menguntungkan sekaligus memberikan peluang bagi masyarakat di sekitar untuk memanfaatkan teknologi tersebut. Penelitian (Palesangi and Muliadi 2012) juga memaparkan cerita sukses anak muda di yang konsen pada kewirausahaan sosial yaitu Goris 
Mustaqim, pendiri dari yayasan Asgar Muda Garut, yayasan yang fokus pada pemberdayaan pemuda (Garut, Jawa Barat). Elang Gumilang menyediakan rumah sederhana dan sehat khusus untuk masyarakat berpenghasilan rendah, dan M. Junerosano pendiri dari Greneration Indonesia, sebuah usaha sosial yang fokus mempromosikan gaya hidup ramah lingkungan. Hal ini menunjukkan bahwa sociopreneur di Indonesia sudah menjadi suatu solusi bagi masalah sosial dan ekonomi yang dilakukan generasi muda sebagai agent of change. Dilansir dari Kementrian Koperasi dan UKM, data BPS menunjukkan adanya pertambahan jumlah pengusaha. Dari sebelumnya 1,6\% menjadi $3,1 \%$ dari populasi dan ini sudah menembus batas psikologis yang ditetapkan yaitu 2\%. Jumlah wirausaha di suatu negara kerap dianggap sebagai indikator kemajuan. Patokannya minimal 2\% dari jumlah penduduk harus berprofesi sebagai wirausaha. Dengan jumlah penduduk 250 juta jiwa, negeri ini paling kurang harus memiliki 5 juta jiwa wirausaha (KOMINFO 2018). Artinya masih banyak peluang untuk menjadi wirausaha di era digital saat ini. Adanya program-program kewirausahaan yang dikembangkan perguruan tinggi diharapkan dapat memberikan pendidikan kewirausahaan bagi lulusan untuk dapat mengisi peluang tersebut.

Pengusaha sosial (social entrepreneur) atau wirausaha sosial dapat disebut sebagai individu visioner yang mampu memberikan solusi kreatif untuk memecahkan beberapa permasalahan sosial yang terjadi di sekitar. Mereka memiliki kemampuan untuk mengidentifikasi masalah, mengembangkan cara untuk mengubah sistem dan menyebarluaskan gagasannya sehingga dapat menggerakkan seluruh masyarakat untuk bekerja sama mengatasi berbagai permasalahan yang dihadapi. Tiga aspek penting dalam pengembangan wirausaha sosial yaitu aspek manusia, aspek keuntungan, dan aspek lingkungan. Hal ini mengidentifikasikan bahwa dalam kewirausahaan sosial harus dapat berjalan secara finansial, sosial, dan lingkungan yang bertanggung jawab.

\section{B. Sociopreneurship dan Perguruan Tinggi}

Setiap manusia pada prinsipnya mempunyai peran sebagai pembawa perubahan demikian juga mahasiswa yang memiliki prinsip kuat sebagai agent of change harus bisa membawa perubahan di lingkungan sekitarnya. Seperti yang sudah diuraikan di atas bahwa sociopreneur bukan hal yang baru, istilah ini sudah ada pada tahun 80an yang dimulai di negara Eropa. Pendidikan Kewirausahaan yang dilakukan oleh perguruan tinggi dalam pendidikan formal diharapkan menghasilkan mahasiswa yang memiliki jiwa wirausaha. Selain itu mahasiswa merupakan bagian kelompok masyarakat yang dinamis. Artinya mahasiswa dapat mengikuti perubahan yang terjadi dalam masyarakat, dan dengan kapasitas intelektualnya mahasiswa mampu mengembangkan diri.

Perguruan tinggi sebagai salah satu fasilitator dalam menghasilkan lulusan sebagai generasi muda yang mempunyai kewajiban mendidik, mengajarkan, melatih dan memotivasi mahasiswanya sehingga menjadi generasi cerdas yang mandiri, kreatif, inovatif, dan mampu menciptakan berbagai peluang pekerjaan (usaha). Sehingga perguruan tinggi perlu kebijakan dan program dalam pengembangan wirausaha dari kalangan mahasiswa sehingga perguruan tinggi bisa menjadi entrepreneur university.

Beberapa perguruan tinggi mulai mengembangkan kewirausaan sosial melalui berbagai program. FISIPOL UGM misalnya, pengembangan program kewirausahaan sosial dilakukan dengan program Akademi Kewirausahaan Masyarakat (AKM). Program AKM ini memberikan kesempatan bagi para sarjana yang belum terserap dunia kerja untuk menekuni kewirausahaan sosial. Program AKM terbagi dalam tiga tahap, yaitu cloning sociopreneurship, deployment sarjana ke pedesaan, dan off-takers produk wirausaha. Tahap awal, AKM fokus pada program cloning berbagai bentuk wirausaha berbasis pedesaan yang telah berhasil. Dalam implementasinya, program AKM melibatkan kelompok bisnis, filantropi, pemerintah pusat dan daerah, sarjana baru lulus, dan komunitas internasional (Alamsyah 2018). Selain itu, pengembangan kewirausahaan dilakukan dengan mengadakan kompetisi dengan judul SOPREMA. British Council dan Arthur Guinness Fund sejak tahun 2010 menyelenggarakan kompetisi dalam pengembangan kewirausahaan sosial yaitu Kompetisi Kewirausahaan Berbasis Komunitas (CEC). Perguruan tinggi lain yang mengembangkan 
kewirausahaan sosial adalah STISIPOL Candramuka Palembang, dengan mendirikan lembaga Pusat Pengembangan Bisnis Dan Kewirausahaan Sosial (P2BKS) diharapkan civitas akademika di lingkungan STISIPOL Candramuka Palembang dapat memahami konsep kewirausahaan sosial. Pemahaman konsep dilakukan dengan pelatihan dan pendampingan. Materi diberikan selama tiga kali pertemuan dengan pendekatan model pembelajaran yang mengedepankan keaktifkan peserta. Selanjutnya adalah objek penelitian yaitu Fakultas Ekonomi UII dalam mengembangkan kewirausahaan dilakukan dengan kompetisi yaitu Social Project Competition. Kompetisi ini merupakan implementasi langsung dari konsep kewirausahaan sosial karena mahasiswa terjun langsung kemasyarakat untuk menerapkan inovasi dan kreatifitas mereka

\section{METODE PENELITIAN}

Penelitian menggunakan metode kualitatif dengan pendekatan deskriptif yang memusatkan pada deskripsi data yang berupa kalimat-kalimat yang memiliki arti mendalam dari informan dan perilaku yang diamati. (Sugiyono 2016). Penelitian kualitatif menurut (Kasiram 2008) dalam adalah suatu proses menemukan pengetahuan yang menggunakan data berupa angka sebagai alat untuk menganalisis keterangan mengenai apa yang ingin diketahui. Sedangkan penelitian deskriptif merupakan suatu metode penelitian yang digunakan untuk menemukan berusaha menggambarkan dan menginterpretasi suatu objek apa adanya pada masa tertentu.

Pengambilan data kualitatif dilakukan dengan cara survei, observasi, studi lapangan, studi literatur dan interview. Survei, observasi, dan studi lapangan dilakukan di daerah yang menjadi objek kegiatan peserta Social Project Competition yaitu Kali Code, Desa Mudal Parangtritis dan Huntap tiga wukirsari Cangkringan. Dalam penelitian ini penulis menggunakan metode wawancara dengan metode in-depth interview atau pertanyaan serta pengamatan langsung terhadap obyek penelitian. Interview dilakukan dengan staf kemahasiswaan yang menjadi panitia kompetisi, peserta, dan warga daerah kegiatan. Menurut Nazir (2014) pengumpulan data adalah prosedur yang sistematik dan berstandar untuk memperoleh data yang diperlukan, beberapa metode yang bisa diterapkan antara lain adalah metode pengamatan langsung, metode dengan menggunakan pertanyaan, metode khusus.

Keterbatasan waktu dan biaya, maka ditetapkan satu perguruan tinggi dengan kriteria belum memiliki lembaga kewirausahaan dan ada materi kuliah kewirausahaan, melaksanakan kegiatan kewirausahaan sosial dan ada keinginan dari civitas akademika untuk membantu masyarakat. Sampel penelitian dipilih dengan purposive random sampling dengan kriteria-kriteria sampel dipertimbangkan oleh penulis. Sampel penelitian adalah mahasiswa Fakultas Ekonomi Universitas Islam Indonesia (FE UII) dengan kriteria sampel yaitu 1) sampel adalah mahasiswa FE UII, 2) peserta Social Project Competition, 3) mau menjadi responden. Kriteria ini merupakan kriteria inklusi dimana subjek penelitian dapat mewakili dalam sampel penelitian yang mempunyai syarat menjadi sampel (Hidayat 2007).

\section{TEMUAN DAN ANALISIS}

Berbagai program kegiatan dilakukan oleh perguruan tinggi untuk menghasilkan wirausaha muda sebagai salah satu solusi atas permasalahan pembanguanan yaitu pengangguran. Di FE UII melakukan beberapa treatment untuk memunculkan di antaranya OCB, Eco Week, Inkubasi Bisnis, dan pendidikan kewirusahaan melalui mata kuliah kewirausahan syariah. Selain itu, wirausahawan berbasis sosial juga menjadi wacana perguruan tinggi sebagai bentuk dharma perguruan dalam pengabdian masyarakat. Di FE UII, program pengembangan Sociopreneurship dilakukan dengan sebuah ajang kompetisi yaitu Social Project Competition.

Program ini merupakan langkah awal penjaringan mahasiswa yang memiliki minat dalam berwirausaha sekaligus membawa perubahan di masyarakat dalam peningkatan kapasistas hidupnya. Kegiatan yang diajukan dalam Social Project Competition dapat berupa keterampilan usaha, penataan dan perbaikan lingkungan, penguatan kelembagaan masyarakat, pengenalan dan pemahaman aspek hukum adat, upaya penyembuhan buta aksara dan 
lain-lain bagi masyarakat baik formal maupun nonformal yang sementara ini dinilai kurang produktif. Hasil wawancara dengan pimpinan PKM Corner Fakultas Ekonomi bapak Arif Wibisono (2018) menyatakan bahwa pengembangan wirausaha diupayakan sedari awal masuk kuliah melalui berbagai program yaitu Carachter Building Orientation di dalamnya ada kegiatan bisnis, inkubasi bisnis, kewirausahaan syariah yang masuk dalam matakuliah serta Social Project Competition untuk wirausaha sosial. Untuk kompetisi ini sudah berjalan selama dua tahun, prosesnya mahasiswa harus mengajukan proposal yang mensyaratkan adanya komitmen dalam bentuk kerjasama tertulis dari komponen masyarakat yang akan dibantu/menjadi khalayak sasaran.

Tujuan kegiatan adalah mengembangkan minat mahasiswa dalam mengabdikan ilmunya kepada masyarakat melalui karya-karya inovatif, kreatif, dan berkelanjutan dalam meningkatkan taraf hidup masyarakat baik kesejahteraan, pendidikan, maupun kesehatan. Selain itu, kegiatan ini diharapkan bisa mencetak sociopreneur yang sukses dan bisa melakukan perubahan pada masyarakat sasaran. Adapun kegiatan ini dimulai bulan Maret-Juli dengan beberapa tahapan yang dilakukan dalam Social Project Competition, yaitu seleksi proposal, presentasi dan pelaksanaan setelah itu monitoring dan evaluasi. Kompetisi ini diikuti oleh mahasiswa aktif di Fakultas Ekonomi UII. Dari hasil seleksi dipilih 10 proposal untuk masuk tahap presentasi setelah itu lima kelompok lolos dan bisa masuk ke tahapan pelaksanaan. Dalam pelaksanaan ini akan dilihat pelaksaanaan setiap kelompok dengan adanya monitoring dan evaluasi. Kompetisi tahun 2018 ini terdapat tiga kandidat akhir yang masuk dalam monitoring dan evaluasi adalah Pemberdayaan Masyarakat dan Pengembangan Ekonomi Pengolahan Sampah Popok di Bantaran Kali Code dengan ketua Miftah Toha Al Haris, Mimpi Kita dengan ketua Muhammad Teguh Pengabdian, Susu Kambing Etawa dengan ketua Latifah Rizki Nurohmah.

4.1 Pemberdayaan Masyarakat dan Pengembangan Ekonomi Pengolahan Sampah Popok di Bantaran Kali Code

Social project pemberdayaan masyarakat dan pengembangan ekonomi pengolahan sampah popok di bantaran Kali Code merupakan salah satu peserta yang termasuk tiga kandidat yang menjadi pemenang kompetisi ini. Dilatarbelakangi dari kepekaan kelompok terhadap masalah sosial yaitu sampah maka kelompok mencoba mencari solusi dengan memanfaatkan sampah tersebut. Dengan sasaran wilayah Kali Code, mahasiswa ini mencoba memberi pengertian kepada warga untuk memanfaatkan sampah rumah tangga daripada dibuang di Kali Code. Sampah yang semakin banyak di pinggir sungai, bantalan kali, dan TPS (Tempat Pembuangan Sementara) akan menyebabkan penumpukan karena tidak adanya pengolahan sampah yang dapat mengurangi penumpukan sampah tersebut. Sampah yang ada di bantalan sungai juga tidak dapat terurai yang menyebakan pencemaran ekosistem dan akan menyebabkan penghambatan arus sungai yang nantinya akan memicu terjadinya banjir.

Akibat dari penumpukan sampah tersebut, masyarakat maupun pemerintah mendapatkan dampak buruk seperti, bau busuk, kotor, dan menyebabkan munculnya berbagai penyakit diare, DBD (demam berdarah) dan sebagainya. Dalam $S_{o-}$ cial Project ini, pemikiran dan gebrakan baru dalam mengolah limbah sampah yang terfokus pada sampah popok sekali pakai dari bayi. Tujuan dari proyek ini agar limbah popok yang ada di masyarakat dapat kita olah menjadi barang bernilai ekonomis. Popok adalah salah satu jenis sampah yang sulit diuraikan ekosistem. Mahasiswa mencoba menjadikan sampah popok ini untuk sesuatu yang bermanfaat bagi warga di daerah Kali Code dan olahan tersebut nantinya akan mempunyai nilai jual lebih selain dari mengurangi populasi sampah popok yang ada. Melalui self water system dikembangkan sebagai bahan dasar popok, ini digunakan pada tanaman yang nantinya akan berguna untuk tanaman mendapatkan memenuhi unsur hara yang dibutuhkan. Penerapan inovasi ini akan diterapkan pada tahapan seedling dan konsep urban farming. Di samping itu, proyek sosial akan dapat dibuat dengan bentuk aksi masyarakat Kali Code yang bersama-sama memanfaatkan limbah popok, dan sebuah sosialisasi penghijauan kampung dengan media sharing kampung yang ada di sekitar Kali Code. Melihat kondisi akan kesadaran peng- 
hijauan yang semakin menurun, penghijauan dapat menjadi sebuah solusi untuk meningkatkan kesadarannya selain memanfaatkan limbah popok disekitar Kali Code. Manfaat dalam sosialisasi pengetahuan tentang inovasi dalam pengembangan self watering system ini nantinya akan berguna pelaksanaan budidaya masyarakat Kali Code dalam sehari-harinya.

Pemanfaatan sampah popok ini adalah sebagai media tanam untuk tanaman hias serta sayur mayur. Masyarakat memberikan ruang bagi mahasiswa untuk memberikan pengajaran pengolahan sampah serta tempat untuk merealisasikan program tersebut. Mulai dari tahapan persiapan yaitu observasi dan sosialisasi, perancangan segala bahan materi sudah tersedia serta uji coba dan terakhir pelaksanaan pelatihan praktik langsung. Mahasiswa juga membuat taman desa dengan menggunakan media tanam untuk bunga hias dari sampah popok yang ditaruh di wadah botol bekas yang diwarnai. Menanam sayur untuk kebutuhan sehari-hari juga dilakukan, hal ini diharapkan bisa mengurangi pengeluaran untuk sayur-mayur nya. Proses usaha dilakukan dengan membuat bank sampah terutama popok. Ke depannya setiap popok yang terkumpul akan ditukar dengan kebutuhan rumah; seperti sabun mandi, deterjen, dan lain-lain. Sehingga kegiatan ini bisa menjadi wirausaha sosial bagi mahasiswa dan masyarakat sekitar Kali Code.

\subsection{Mimpi Kita}

Mimpi Kita merupakan social project mahasiswa yang berkaitan dengan permasalahan pembangunan yaitu peningkatan indeks melek huruf di kalangan masyarakat. Kualitas Sumber Daya Manusia (SDM) merupakan salah satu yang memengaruhi pembangunan suatu bangsa. SDM yang baik tidak akan bisa lepas dari proses pendidikan, baik itu formal maupun informal. Dari keinginan kuat sekelompok mahasiswa untuk mencerdaskan bangsa itulah maka didirikanlah kelompok belajar "Mimpi Kita" yang berada di Desa Mudal, Parangtritis, Gunung Kidul. Selain peningkatan kemampuan kognitif masyarakat, kelompok ini mencoba untuk meningkatkan perekonomian agar tercipta masyarakat desa yang mandiri secara finansial sehingga mampu membiayai pendidikan generasi muda yang ada di sana.
Pemetaan potensi sudah dilakukan pada tahap pra-poposal dan didapat bahwa desa tersebut pendidikan anak yang lulusan Sekolah Menengah Atas (SMA) sangat minim, banyak anak-anak yang putus sekolah atau pendidikan hanya sampai Sekolah Menengah Pertama (SMP) saja. Penduduk Desa Mudal sebanyak 65 orang, 20 di antaranya anakanak, 10 anak sedang mengenyam pendidikan SMP. Sedangkan mengenai pendidikan yang lebih lanjut di tingkat SMA tidak ada dikarenakan tidak adanya bantuan dari pemerintah berupa Bantuan Operasional Sekolah (BOS). Dilihat dari potensi ekonominya, Desa Mudal memiliki banyak pohon melinjo, pohon kelapa, dan pekarangan yang belum dimanfaatkan secara maksimal.

Kegiatan yang dilakukan menggabungkan aspek verbal, agama, dan bisnis. Aspek verbal tercermin pada kegiatan pembelajaran bahasa Inggris dan bahasa Arab dasar. Aspek agama tercermin pada kegiatan perbaikan bacaan Alquran, dan aspek bisnis tercermin pada kegiatan pembelajaran bisnis melalui teknologi informasi. Seminggu tiga kali kegiatan pembelajaran sekolah non-formal dilakukan. Selama kegiatan dilakukan proses pemberdayaan seperti pelatihan pemanfaat potensi misalnya sosis dari kulit mlinjo yang bekerjasama dengan peserta kompetisi bussines plan, pembuatan kandang untuk ternak mentok yang berkerjasama dengan pemuda desa muda yang tujuan untuk meningkatkan perekoniman warga di Desa Mudal. Sehingga kedepannya kegiatan tersebut mampu untuk membiayai pendidikan anak-anak disana dan ikut melaksanakan program pembangunan yaitu melek huruf. Hasil monitoring wirausaha sosial yang dilakukan memang belum menuai hasil maksimal karena itik yang diternak baru.

\subsection{SUKAWA (Susu Kambing Etawa)}

Pengembangan Sociopreneur dilakukan di Cangkringan Huntap 3 Dongkelsari, sebuah desa yang memiliki potensi susu kambing etawa yang cukup karena warga desa mempunyai kandang komunal untuk budidaya kambing tersebut. Selama ini hasil susu kambing etawa belum optimal meningkatkan taraf hidup warga karena produknya masih berupa susu cair dan belum ada inovasi dari produk tersebut. 
Melihat hal tersebut, mahasiswa berinisiatif untuk membantu menyelesaikan permasalahan dengan cara membantu pemasaran, mengajarkan pencatatan akuntansi penjualan, serta mengajarkan pengolahan inovasi produk kesehatan dengan memanfaatkan susu kambing etawa untuk dijadikan sabun sebagai usaha warga, sehingga peternak kambing di Huntap Dongkelsari dapat aktif dengan maksimal kembali.

Adanya pengolahan susu kambing etawa ini menjadi sabun mandi dan masker kecantikan, diharapkan dapat meningkatkan penghasilan bagi warga peternakan kambing tersebut dan masyarakat sekitarnya. Selain membuka peluang usaha bagi penduduk sekitar, pengolahan susu kambing etawa menjadi sabun mandi dan masker kecantikan juga dapat memaksimalkan penggunaan susu kambing menjadi produk yang bernilai ekonomis. Beberapa tahapan dilakukan dari survei lokasi mengurus perizinan kepada perangkat dusun atau desa setempat berkaitan dengan pengenalan dan pengarahan pemanfaatan susu kambing etawa sebagai komoditi baru yang cukup menguntungkan dan bahan baku pembuatan produk. Tim juga melakukan koordinasi dengan karang taruna setempat untuk membantu memasarkan produk yang telah dihasilkan nantinya. Langkah selanjutnya adalah memberikan pengarahan bagaimana cara untuk membuat masker wajah berbahan dasar susu kambing etawa. Target program adalah peternak dan Ibu-ibu PKK serta karang taruna di Huntap
Dongkelsari untuk mengolah susu kambing etawa menjadi produk sabun mandi dan masker wajah.

Proses monitoring dan evaluasi dilakukan setelah beberapa bulan program berjalan sehingga akan terlihat dampaknya. Dari hasil monitoring dan evaluasi, ibu-ibu PKK Desa Dongkel Sari sudah mulai melakukan inovasi olahan susu dan memasarkanya walaupun masih sebatas internal desa saja. Program ini diharapkan dapat menjadi suatu membawa dampak perubahan taraf ekonomi masyarakat melalui potensi yang sudah dimilikinya.

Hal yang menarik untuk dicermati dari ketiga peserta Social Project di atas adalah adanya kesamaan yaitu status mahasiswa, berjiwa wirausaha, kreatif dan inovatif, serta memiliki kepedulian sosial yang tinggi. Pemuda seperti mereka yang bisa memadukan antara aktifitas sosial dan bisnis sangat dibutuhkan bangsa ini. Perjalanan ketiga tim muda ini tentunya masih panjang untuk membuktikan diri sebagai wirausaha sosial yang sejati, namun inisiatif mereka perlu kita apresiasi secara khusus karena mereka tidak sekadar mengembangkan bisnis tapi juga memberikan solusi persoalan sosial ekonomi masyarakat. Beberapa peran yang telah dilakukan adalah memberikan inovasi terkait potensi yang dimiliki masyarakat yeng menjadi objek kegiatan, memberikan pelatihan produksi sampai pada pemasaran terutama untuk yang SUKAWA. Untuk lebih jelasnya bisa dilihat pada tabel berikut:

Tabel.1 Elemen Sociopreneur (kewirausahaan Sosial) peserta Social Project Competition

\begin{tabular}{|c|c|c|c|}
\hline \multirow[b]{2}{*}{$\begin{array}{c}\text { Elemen } \\
\text { Sociopreneurship }\end{array}$} & \multicolumn{3}{|c|}{ Peserta Social Project } \\
\hline & $\begin{array}{c}\text { Peserta } 1 \\
\text { (Pengolahan Popok Kali } \\
\text { Code) }\end{array}$ & $\begin{array}{c}\text { Peserta } 2 \\
\text { ( Mimpi Kita) }\end{array}$ & $\begin{array}{c}\text { Peserta } 3 \\
\text { ( SUKAWA: Inovasi Produk Susu } \\
\text { Kambing Etawa) }\end{array}$ \\
\hline Social Value & $\begin{array}{l}\text { Masyarakat menjadi lebih } \\
\text { peduli lingkungan }\end{array}$ & $\begin{array}{c}\text { Masyarakat lebih } \\
\text { peduli pendidikan anak }\end{array}$ & $\begin{array}{l}\text { pemuda peternak kambing } \\
\text { dan ibu-ibu PKK memiliki } \\
\text { wadah menciptakan bisnis } \\
\text { berbasis komunitas }\end{array}$ \\
\hline Civil Society & Masyarakat Umum & $\begin{array}{c}\text { Anak-anak usia } \\
\text { sekolah, warga desa } \\
\text { Mudal }\end{array}$ & $\begin{array}{l}\text { mengolah berbagai varian produk } \\
\text { berbahan baku susu kambing }\end{array}$ \\
\hline Innovation & $\begin{array}{l}\text { Memadukan produk dan } \\
\text { program untuk } \\
\text { mengkampanyekan } \\
\text { pelestraian lingkungan }\end{array}$ & $\begin{array}{l}\text { Memadukan pembelajaran } \\
\text { kognitif dan bisnis }\end{array}$ & $\begin{array}{l}\text { Mengolah berbagai varian } \\
\text { produk berbahan baku dari } \\
\text { susu kambing }\end{array}$ \\
\hline Economic Activity & $\begin{array}{l}\text { Bank sampah popok, } \\
\text { penanaman tanaman } \\
\text { rumah tangga }\end{array}$ & $\begin{array}{l}\text { Membuat kandang } \\
\text { komunal untuk entok }\end{array}$ & $\begin{array}{l}\text { Pendirian rumah susu } \\
\text { (inovasi berbagai olahan susu) }\end{array}$ \\
\hline
\end{tabular}


Tabel di atas menunjukkan bahwa pengembangan kewirausahaan yang dilakukan telah memenuhi konsep kewirausahaan sosial. Social Value, ketiga peserta dalam menerapkan inovasi dan kreatifitasnya memberikan manfaat sosial baik langsung maupun tidak langsung kepada masyarakat objek kegiatan baik di Desa Mudal, Desa Cangkringan maupun di Kali Code. Peserta memberikan keterampilan dan kemampuan yang dimilki kepada warga untuk memanfaatkan peluang bisnis dari potensi yang ada. Ketiga peserta Social Project Competition memiliki tujuan untuk membantu masyarakat mencari peluang bisnis dengan memberikan keterampilan sehingga tercipta suatu wadah bisnis berbasis komunitas. Mimpi kita misalnya, peserta membuat peternakan entok sebagai pilot project dalam pengembangan usaha warga Desa Mudal untuk bisa membayar biaya pendidikan anak. Civil Society, pelibatan objek kegiatan (modal sosial) dalam pengembangan kewirausaan sosial akan menjadikan keberhasilan dari peserta kompetisi. Peserta pemberdayaan pengolahan limbah popok menjadikan masyarakat sebagai potensi yang perlu dikembangkan. Sedangkan untuk Mimpi Kita lebih pada anak-anak usia sekolah. SUKAWA memprioritaskan pengembangan potensi pada ibu-ibu PKK. Optimalisasi modal sosial dilahirkan dari adanya inisiatif yang dimiliki oleh pengusaha sosial (Hulgard 2010). Inovation, kewirausaan sosial memadukan konsep kreatif dan inovatif. Konsep ini didasari dari ide yang unik yang memberikan nilai tambah pada ide, barang, kejadian, dan metode yang diangap sebagai hal yang baru oleh masyarakat (Hulgard 2010). Inovasi yang dilakukan ketiga peserta Social Project Competition berbeda-beda, pemberdayaan masyarakat di bantaran Kali Code berinovasi melalui limbah popok, limbah popok yang diolah menjadi media tanam yang sekaligus membantu mengkampanyekan kelestarian lingkungan. Sedangkan untuk mimpi kita, berinovasi dengan mendirikan program pendidikan dengan berbagai metode pembelajaran, sekaligus memetakan potensi dan hasil pemetaan di diskusikan dengan warga Desa Mudal untuk dikembangkan. Peserta tiga melakukan inovasi dengan membuat sabun dari susu kambing. Elemen terakhir adalah Economic Activity, sesuai dengan tujuan pengembangan kewirausahaan sosial yaitu menyeleseikan masalah dengan bisnis, maka kegiatan Social Project Competition juga harus bisa membawa dampak peningkatan ekonomi masyarakat, dalam hal ini keselarasan antara aktifitas sosial sangat diperlukan. Untuk menjaga keselarasan antara aktifitas sosial dan ekonomi sehingga terjamin kemandirian dan keberlanjutan, maka misi sosial yang harus dikembangkan adalah menjaga hak dan kewajiban serta menjalin rasa kekeluargaan (Prayogo 2017). Aktifitas ekonomi pemberdayaan masyarakat di bantaran Kali Code ke depannya adalah adanya bank limbah popok untuk tempat pengolahan kemudian memberikan penukaran bagi pengumpul popok. Selain itu, media tanam akan ditanami tanaman untuk keperluan keluarga seperti sawi, terong, dan lain-lain sehingga terjadi penghematan untuk pengeluaran konsumsi. Sedangkan Mimpi Kita, aktifitas ekonomi yang dikembangkan melalui peternakan entok, peserta sospro memberikan bibit entok dan kandang entok untuk kemudian dikelola masyarakat sehingga hasilnya bisa digunakan untu bisnis warga Desa Mudal. Untuk SUKAWA, aktifitas ekonomi yang dilakukan melalui pengaktifan kembali rumah susu yang sudah lama mati suri untuk bisa digunakan sebagai tempat pengolahan sekaligus usaha berbagai produk dari susu kambing bagi ibu-ibu PKK di Hunian Tetap 3 daerah Wukirsari Cangkringan.

\section{KESIMPULAN}

Kegiatan Social Project menjadi sangat penting dalam membangun kemandirian mahasiswa di tengah himpitan mencari kerja. Perguruan tinggi harus bisa menciptakan lulusan yang siap menghadapi kompetisi kerja dan mampu menciptakan peluang kerja dengan memberikan pengatahuan dan keterampilan berwirausaha yang mempunyai tingkat kepekaan sosial tinggi sehingga dapat mengubah lingkungan di sekitarnya. Hasil penelitian menunjukkan bahwa dampak yang dirasakan oleh ketiga objek kegiatan yaitu Kali Code, Desa Mudal Parangtritis dan Huntap 3 Wukirsari Cangkringan sesuai dengan elemen kewirausahaan sosial.

Hasil yang paling terlihat dari adanya kompetisi ini adalah meningkatnya pengetahuan masyarakat berkaitan dengan keterampilan sebagai 
modal untuk memperoleh nilai tambah sehingga dapat meningkatkan pendapatan masyarakat. Berdasarkan gambaran peserta kompetisi yang lolos tahap pelaksanaan dapat disimpulkan bahwa ajang kompetisi ini bisa menghasilkan sociopreneur yang bisa mengubah masyarakat untuk hidup lebih baik dari segi pendidikan, kesehatan, maupun ekonomi. Artinya kegiatan ini dapat memberikan manfaat bagi mahasiswa yang bersangkutan, masyarakat dan juga bagi Perguruan Tinggi seperti memberikan keseimbangan kemampuan akademis, kemampuan bersikap, dan kemampuan berkarya dalam rangka menuju pengembangan diri, masyarakat baik sebagai wirausaha sosial yang profesional, mandiri, dan inovatif dalam melihat peluang yang ada. Sehingga bisa memanfaatkan potensi seperti membuat rumah baca yang dilakukan peserta dua dan rumah susu untuk membuat beraneka produk dari susu kambing seperti sabun mandi serta inovasi membuat media tanam dari popok untuk membuat taman di Kali Code.

\section{DAFTAR PUSTAKA}

Alamsyah, Iikhsan Emerad. 2018. "C-Hub Fisipol Kembangkan Program Kewirausahaan Sosial Melalui AKM." Republika. Retrieved November 7, 2018 (www.republika.co.id/berita/pendidikan/edukation).

Dees, J. Gregory. 2001. The Meaning of Social Entrepreneurship. Kauffman Foundation.

Hidayat. 2007. Metode Penelitian Keperawatan Dan Teknik Analisa Data. Surabaya: Salemba medika.

Hulgard, Lars. 2010. Discourses of Social Entrepreneurship-Variation of The Same Theme.

Kasiram. 2008. Metodologi Penelitian Kuantitatif -Kualitatif. Malang: UIN Malang Press.

KOMINFO, Kementrian. 2018. "Peluang Besar Jadi Pengusaha Di Era Digital." Retrieved November 9, 2018 (https://kominfo.go.id/content/ detail/9503/peluang-besar-jadi-pengusaha-di-era-digital/0/berita).
Kusumasari, Suyatna and Dkk. 2015. Memahami Model Bisnis Organisasi Sosial (Social Entrepreneurship) Di Indonesia. Yogyakarta: Gava Media.

Masturin. 2015. "Model Pemberdayaan Masyarakat Dengan Pendekatan Social Entrepreneurship: Analisis Ketokohan Para Pewirausaha Sosial." INFERENSI, Jurnal Penelitian Sosial Keagamaan 9(1):159-82.

Nazir. 2014. Metode Penelitian. Bogor: Ghalia Indonesia.

Nicholls, A. 2006. "Playing the Field: A New Approach to the Meaning of Social Entrepreneurship." Social Enterprise Journal 2(1):1-5.

Noruzi, M., J. Westover, and G.Rahimi. 2010. “An Exploration of Social Entrepreneusrhip in the Entrepreneurship Era." Asian Social Science $6(6): 3-10$.

Palesangi and Muliadi. 2012. "Pemuda Indonesia Dan Kewirausahaan Sosial." Pemuda Indonesia Dan Keiwarusahaan Sosial 1(94).

Patra, S.and S.Nath. 2014. "Social Transformation through Social Entrepreneusrhip: An Exploratory Study. , XI(1): 7-17." The IUP Journal of Entrepreneurship Development 11(1):7-17.

Prayogo, Caroline. 2017. "Studi Deskriptif Social Entrepreneur Pada Pemilik Agfa Di Sidoarjo, Jawa Timur, Indonesia." AGORA 5(1):1-6.

Santoso, Setyanto. 2007. Peran Social Entrepeneur Dalam Pembangunan. Malang.

Sugiyono. 2016. Metodologi Penelitian Kuantitatif, Kualitatif, Dan R\&D. Bandung: CV. Alfabeta.

Suyatna, Hempri and Yanti Nurhasanah. 2017. "Sociopreneurship Sebagai Tren Karir Anak Muda." Jurnal Studi Pemuda 6(1):527-37.

Tan, Wee-Liang, John Williams, and Teck-Meng Tan. 2005. "Defining the 'Social' in 'Social Entrepreneurship': Altruism and Entrepreneurship." The International Entrepreneurship and Management Journal 1(3):353-65.

Wiguna, Atu Bagus. 2013. "Social Entrepreneurship Dan Socio-Entrepreneurship: Tinjauan Dengan Perspektif Ekonomi Dan Sosial.” Jurnal Ilmiah Mahasiswa FEB 1(1). 